\title{
PENGARUH DISIPLIN TENAGA KEPENDIDIKAN TERHADAP PELAYANAN ADMINISTRASI AKADEMIK FAKULTAS TARBIYAH DAN KEGURUAN UIN ALAUDDIN MAKASSAR
}

\author{
Kasmawati \\ Fakultas Tarbiyah dan Keguruan UIN Alauddin Makassar \\ Kampus II: Jalan Sultan Alauddin Nomor 36 Samata-Gowa \\ Email: kasmawatiuin@yahoo.com
}

\begin{abstract}
Abstrak:
Pengembangan sumber daya manusia didefinisikan sebagai proses menentukan persyaratan dan peralatan untuk memenuhi persyaratan tersebut agar dapat melaksanakan rencana organisasi yang terintegrasi. Untuk itu diperlukan adanya perencanaan sumber daya manusia yang mempunyai tujuan berdasarkan kepentingan individu dalam organisasi karena dapat membantu meningkatkan potensinya, begitu pula dapat dicapai melalui perencanaan karir. Kepentingan organisasi sumber daya manusia sangat bermanfaat bagi organisasi dan dapat dipersiapkan calon-calon pegawai yang mempunyai potensi untuk menduduki posisi manajer/pimpinan. Kepentingan nasional dapat dimanfaatkan oleh pemerintah dalam rangka meningkatkan produktifitas nasional.
\end{abstract}

\begin{abstract}
:
Development of human resource has been defined as the prosess of determining manpower requirements and the means for meeting those requirements in order to carry out the plans of the integrated organization. Therefore, it is necessary to have a human resources planning that the goals are based on individual interest in an organization, because it can help to improve the potency, as well as can be achieved through career planning. The importance of human resources organization is beneficial for the organization and can prepare prospective employees who have the potential to occupy the position of manager/leader. Nasional Importance is also able to be used by the government in order to improve national productivity.
\end{abstract}

Kata kunci:

Disiplin, Tenaga Kependidikan, (SDM)Pelayanan Akademik

ORGANISASI yang berhasil adalah yang secara efektif dan efisien mengkombinasikan sumber-sumber dayanya guna menerapkan sumber strategi-strateginya. Namun demikian, yang menjadi pusat strategi untuk setiap penggunaan sumber daya adalah tenaga kependidikan yang merencanakan dan melaksanakan strategi-strategi sebuah organisasi.

Arti penting dari upaya-upaya sumber daya manusia adalah bermuara dari kenyataan bahwa manusia merupakan elemen yang selalu ada di dalam setiap organisasi. Sumber daya manusia membuat sumber-sumber daya organisasi lainnya berjalan. Organisasi tidak akan dapat memaksimalkan produktivitasnya tanpa ada karyawan kompeten yang berdedikasi terhadap tujuan organisasi.

Pada kenyataannya bahwa manusia bukan hanya memiliki berbagai ciri dan kemampuan yang tidak dimiliki oleh alat produksi lainnya dalam organisasi, tetapi jauh 
lebih penting dari semua itu adalah karena manusia mempunyai harkat dan martabat yang harus diakui, dihargai dan dijunjung tinggi. Hanya dengan demikianlah faktor manusia di dalam organisasi manjadi faktor yang benar-benar mampu memainkan peranan yang dominan dan bahkan menentukan dalam usaha pencapaian tujuan organisasi yang bersangkutan .

Tenaga Kependidikan (SDM) yang paling penting bagi suatu organisasi adalah tenaga kerja dalam hal ini tenaga kependidikan yang mempunyai bakat, kreativitas, dan semangat kepada organisasi. Oleh karena itu kesulitan sumber daya manusia merupakan sumber masalah dalam organisasi. Konsekuensi dari hal ini adalah tersedianya sumber daya manusia yang mempunyai kapasitas sebagai perencana dan pelaksana program kegiatan. Kapasitas ini ditentukan oleh kapabilitas, kompotensi dan produktivitas kerja.

Kapabilitas sumber daya manusia yang berorientasi pada pengetahuan (knowledge) dan keterampilan (skill) yang akan menentukan berhasilnya seorang menyelesaikan pekerjaan yang dibebankan kepadanya secara optimal.

Masalah sumber daya manusia masih menjadi sorotan dan tumpuan bagi perusahaan untuk tetap dapat bertahan di era globalisasi. Sumber daya manusia mempunyai peran utama dalam setiap kegiatan perusahaan/organisasi. Walaupun didukung dengan sarana dan prasarana serta sumber dana yang berlebihan, tetapi tanpa dukungan sumber daya yang handal kegiatan perusahaan/organisasi tidak akan terselesaikan dengan baik. Hal ini menunjukkan bahwa sumber daya manusia merupakan kunci pokok yang harus diperhatikan dengan segala kebutuhannya.

Sebagai kunci pokok, sumber daya manusia akan menentukan keberhasilan pelaksanaan kegiatan suatu lembaga/organisasi/perusahaan. Tuntutan perusahaan untuk memperoleh, mengembangkan dan mempertahankan tenaga kependidikan (SDM) yang berkualitas semakin mendesak sesuai dengan dinamika lingkungan yang selalu berubah. Perubahan perlu mendapat dukungan manajemen puncak sebagai langkah pertama yang penting untuk dilakukan bukan hanya sekedar lip service saja. Pemimpin harus dapat memobilisasi sebuah tim, proses pekerjaan harus dapat dikembangkan dan proses sumber daya manusia harus menjadi fokus utama.

Perubahan dan peningkatan peran fungsi sumber daya manusia sangat esensial untuk mendukung keberhasilan organisasi. Pengelolaan sumber daya manusia terkait dan mempengaruhi kinerja organisasional dengan cara menciptakan nilai atau menggunakan keahlian sumber daya manusia yang berkaitan dengan praktek manajemen dan sasarannya cukup luas, tidak hanya terbatas karyawan operasional semata, namun juga meliputi tingkatan manajerial.

Tenaga Kependidikan (SDM) sebagai penggerak lembaga organisasi banyak dipengaruhi oleh perilaku para pesertanya (partisipasinya) atau aktornya. Keikutsertaan sumber daya manusia dalam organisasi diatur dengan adanya pemberian wewenang dan tanggung jawab. Merumuskan wewenang dan tanggung jawab yang harus dicapai tenaga kependidikan dengan standar atau tolak ukur yang telah ditetapkan dan disepakati oleh karyawan dan atasan. Karyawan bersama atasan masing-masing 
dapat menetapkan sasaran kerja dan standar kinerja yang harus dicapai serta menilai hasil-hasil yang sebenarnya dicapai pada akhir kurun waktu tertentu.

Peningkatan kinerja pegawai secara perorangan akan mendorong kinerja sumber daya manusia secara keseluruhan, yang direkflesikan dalam kenaikan produktivitas. Kondisi kinerja khusunya PNS sebagai tenaga kerja telah lama menjadi sorotan publik. Kinerja PNS dinilai masih sangat rendah dalam memberikan pelayanan kepada masyarakat ataupun mahasiswa sikap mental sebagian pegawai pada suatu instansi tertentu nampak cenderung lebih ingin dilayani daripada melayani, kurangnya disiplin kerja, rendahnya pemahaman terhadap tanggung jawab pelaksanaan dan penyelesaian tugas-tugasnya, dan lain sebagainya.

Keputusan Menteri Agama RI No 93 Th 2007 tentang STUTA Universitas Islam Negeri Alauddin Makassar, Perubahan status Institut Agama Islam Negeri (IAIN) Alauddin menjadi Universitas Islam Negeri Alauddin Makassar (UIN) menjadikan peran dan fungsi pegawai pada lembaga ini berubah pula. Dengan perubahan tersebut telah mendorong setiap pegawai perlu meningkatkan kinerjanya dan organisasinya dalam merespon berbagai tuntutan akan kualitas pelayanan, pelaksanaan pembangunan serta dalam rangka menunjang kelancaran administrasi di Universitas Islam Negeri Makassar. Hal Ini bukanlah pekerjaan yang mudah atau ringan mengingat sulitnya mengubah paradigma dan perilaku setiap PNS.

Fakta lain yang juga terjadi dimana terdapat beberapa pegawai menempati suatu posisi jabatan yang kurang sesuai dengan tingkat pendidikan/latar belakang disiplin ilmu, kemampuan/kecakapan kerja, pengalaman masa kerja dan lainnya. Ini juga megindikasikan lemahnya job description dalam penempatan pegawai pada jabatan tertentu. Selain itu, kondisi lingkungan kerja yang sudah dilengkapi sejumlah peralatan sedemikian rupa mulai dari peralatan administrasi, penataan ruangan kerja sampai kepada kebutuhan peralatan operasional. Sejumlah fasilitas seperti tunjangan, honorarium, insentif dan lainnya juga nampak dianggarkan dalam anggaran kinerja instansi tersebut, namun motivasi pegawai untuk memacu prestasinya juga kurang nampak menunjukkan hasil yang diharapkan.

\section{PEMBAHASAN}

\section{Konsep Sumber Daya Manusia}

Manusia merupakan sumber daya yang paling penting dalam usaha suatu organisasi (instansi pemerintah atau perusahaan) untuk mencapai keberhasilan. Sumber daya manusia menunjang organisasi dengan karya, bakat, kreativitas dan dorongan (motivasi) serta inovasi. Oleh karena itu dapat dikatakan bahwa meskipun aspek teknologi dan aspek-aspek lainnya telah sempurna dalam organisasi, tetapi jika tidak ditunjang oleh aspek manusia, maka organisasi tersebut sulit mencapai tujuan-tujuan yang telah ditetapkan sebelumnya. Sumber daya manusia merupakan salah satu unsur masukan (input) yang bersama-sama dengan faktor produksi lainnya. Seperti bahan baku, mesin dan teknologi digunakan untuk mengubah bahan baku melalui 
suatu proses manajemen menjadi produk (output), berupa barang dan jasa, dalam usaha untuk mencapai tujuan organisasi/perusahaan. Kegiatan ini merupakan aktivitas utama yang dilakukan oleh perusahaan atau instansi pemerintah dalam kapasitas fungsinya sebagai pelaku ekonomi dalam perekonomian suatu masyarakat atau negara. Tujuan utamanya adalah untuk menghasilkan barang dan jasa yang dibutuhkan oleh para pelaku ekonomi lainnya, utamanya rumah tangga, guna memenuhi kebutuhan mereka dalam mengejar kesejahteraannya dari waktu ke waktu. Di lain pihak perusahaan melakukan kegiatan tersebut untuk mencapai tujuannya, yakni untuk memperoleh keuntungan yang dapat digunakan untuk mengembangkan usahanya.

Salah satu bagian dari ilmu manajemen yang memfokuskan diri untuk mengelola unsur manusia seefektif mungkin agar diperoleh suatu satuan tenaga kerja yang puas dan memuaskan adalah manajemen sumber daya manusia yang merupakan cabang ilmu manajemen umum yang khusus menelaah aspek manusia dalam suatu organisasi atau peusahaan, mulai dari aspek perencanaan pengadaannya sampai pada aspek pengembangan dan pemeliharaannya. ${ }^{1}$

Selain itu, Nitisemito telah mengemukakan bahwa manajemen sumber daya manusia (manajemen personalia) adalah suatu ilmu dan seni untuk melasanakan antara lain: Planning, Organizing, Controlling, sehingga efektivitas dan efiensi personalisasi (sumber daya manusia) dapat ditingkatkan semaksimal mungkin dalam pencapaian tujuan. ${ }^{2}$

Selanjutnya, Simamora mengemukakan bahwa manajemen personalia (sumber daya manusia) adalah perencanaan sumberdaya manusia, staffing, dan penelitian pegawai, training, dan pengembangan, pemberian balas jasa, tunjangan sosial dan pelayanan terhadap pegawai, tunjangan kesehatan dan keamanan. ${ }^{3}$

Dari gambaran di atas dapat diketahui bahwa fungsi manajemen sumber daya manusia itu penting dalam suatu perubahan karena merupakan bagian dari ilmu manajemen itu sendiri yang khusus bertugas untuk mengelolah semua unsur manusia yang ada dalam perusahaan/organisasi, sehingga penggunaannya dapat efektif guna pencapaian tujuan perubahan.

Selanjutnya, dari uraian di atas dapat pula dilihat bahwa manajemen sumber daya manusia mempunyai fungsi operatif yang dapat dijelaskan secara satu persatu sebagai berikut:

a. Pengadaan tenaga kerja (Prorecruitment)

Fungsi ini membahas tentang cara untuk mendapatan sejumlah tenaga kerja (pegawai) yang dibutuhkan dengan kualitas tertentu dalam rangka mencapai tujuan perusahaan atau organisasi. Oleh karena itu fungsi ini terutama menyangkut mengenai penentuan kebutuhan tenaga kerja dan penempatannya.

b. Pengembangan tenaga kerja (pegawai)

Fungsi ini membahas mengenai pengembangan kecakapan para pegawai dengan cara memberian pelatihan (training) sesuai dengan yang diperlukan untuk pelaksanaan. 


\section{Konsep Kinerja dan Sumber Daya (SDM)}

\section{Beberapa Pengertian}

Terminologi kinerja berasal dari terjemahan kata "Performance" yang berarti "penampilan atau prestasi". Murfhy dan clevelland mendefinisikan performance sebagai countable outcome. ${ }^{4}$ Bermandirn dan Russel Menjelaskan bahwa kinerja (performance) adalah hasil dari fungsi suatu pekerjaan atau kegiatan tertentu selama suatu periode waktu tertentu. ${ }^{5}$ Ada tiga aspek yang perlu dipahami setiap PNS atau pimpinan suatu lembaga dan organisasi kerja, yakni:

a. Kejelasan tugas atau pekerjaan yang menjadi tanggung jawabnya;

b. Kejelasan hasil (indikator) yang diharapkan dari suatu pekerjaan atau fungsi;

c. Waktu yang diperlukan untuk menyelesaikan suatu pekerjaan agar hasil yang diharapkan dapat terwujud.

Kinerja SDM merupakan istilah yang berasal dari kata Job Performance atau Actual Performance (prestasi kerja atau prestasi sesugguhnya yang dicapai seseorang). Kusriyanto B., mendefenisikan kinerja karyawan yaitu ada "perbandingan hasil yang dicapai dengan peran serta tenaga kerja persatuan waktu (lazimnya perjam)". ${ }^{6}$ Gomes mendefinisikan kinerja karyawan sebagai "ungkapan seperti output, efisiensi serta efektivitas sering dihubungkan dengan produktivita".7 Mangkunegara menjelasan bahwa "kinerja karyawan (prestasi kerja) adalah hasil kerja secara kualitas dan kuantitas yang dicapai oleh seseorang karyawan dalam melaksanakan tugasnya sesuai dengan tanggung jawab yang diberikan kepadanya".8

Berdasarkan uraian pendapat di atas, dapat disimpulkan bahwa kinerja SDM adalah prestasi kerja atau hasil kerja output, baik kualitas maupun kuantitas yang dicapai SDM persatuan periode waktu dalam melaksanakan tugas kerjanya sesuai dengan tanggung jawab yang diberikan kepadanya.

\section{Pengertian Evaluasi/Penilaian Kerja}

Evaluasi kinerja atau penilaian prestasi karyawan yang dikemukakan Mengginsion adalah "penilaian atau prestasi kerja (performance) seseorang karyawan melakukan pekerjaannya sesuai dengan tugas dan tanggung jawabnya". 9 Selanjutnya Sikula mengemukakan bahwa "penilaian pegawai merupakan evaluasi yang sistematis dan pekerjaan pegawai dan potensi yang dapat dikembangkan. Penilaian dalam proses penafsiran atau penentuan nilai, kualitas atau status dan beberapa obyek orang ataupun sesuatu (barang)"..10

Dari beberapa pendapat ahli tersebut, dapat disimpulkan bahwa evaluasi kinerja adalah penelitian yang dilakukan secara sistematis untuk mengetahui hasil pekerjaan karyawan dan kinerja organisasi. Di samping itu, juga untuk menentukan kebutuhan pelatihan kerja secara tepat, memberikan tanggung jawab yang sesuai kepada karyawan sehingga dapat melaksanakan pekerjaan yang lebih di masa mendatang dan sebagai dasar untuk menentukan kebijakan dalam hal promosi jabatan atau penentuan imbalan. 


\section{Tujuan Penilaian/Evaluasi Kinerja}

Tujuan evaluasi kinerja adalah untuk memperbaiki atau meningkatkan kinerja organisasi melalui peningkatan kinerja dan SDM organisasi. Secara lebih spesifik, tujuan dan evaluasi kinerja sebagaimana dikemukakan Sunyoto adalah:

a. Meningkatkan saling pengertian antara karyawan tentang persyaratan kinerja.

b. Mencatat dan mengakui hasil kinerja seorang karyawan, sehingga mereka termotivasi untuk berbuat yang lebih baik, atau sekurang-kurangnya berprestasi sama dengan prestasi yang terdahulu.

c. Memberikan peluang kepada karyawan untuk mendiskusikan keinginan dan aspirasinya dan meningkatkan kepedulian terhadap karir atau terhadap pekerjaan yang diembannya sekarang. ${ }^{11}$

\section{Sasaran Penilaian/Evaluasi Kinerja}

Sasaran-sasaran dan evaluasi kinerja karyawan yang dikemukakan Sunyoto sebagai berikut:

a. Membuat analisa kinerja dan waktu yang lalu secara berkesinambungan dan periodik, baik kinerja karyawan maupun kinerja organisasi.

b. Membuat evaluasi kebutuhan pelatihan dan para karyawan melalui audit keterampilan dan pengetahuan sehingga dapat mengembangkan kemampuan dirinya. Atas dasar evaluasi kebutuhan pelatihan itu dapat menyelenggarakan program pelatihan dengan tepat. ${ }^{12}$

\section{Prinsip Dasar Penilaian/Evaluasi Kinerja}

Secara singkat dapat disimpulkan bahwa prinsip dasar evaluasi kinerja sebagai berikut:

a. Fokusnya adalah membina kekuatan untuk menyelesaikan setiap persoalan yang timbul dalam pelaksanaan evaluasi kerja. Jadi bukan semata-mata menyelesaikan persoalan itu sendiri, namun pimpinan dan karyawan mampu mempersoalkan dengan baik setiap saat, setiap ada persoalan baru. Jadi yang penting adalah kemampuannya.

b. Selalu didasarkan atas suatu pertemuan pendapat, misalnya dari hasil diskusi antara karyawan dengan penyelia langsung, suatu diskusi yang konstruktif untuk mencari jalan yang terbaik dalam meningkatkan mutu dan baku yang tinggi. ${ }^{13}$

\section{Aspek-Aspek Standar Pekerjaan dan Kinerja Tenaga Kependidikan}

Hasibuan mengemukakan bahwa aspek-aspek yang dinilai kinerja mencakup: kesetiaan, hasil kerja, kejujuran, kedisiplinan, kreativitas, kerjasama, kepemimpinan, kepribadian, prakarsa, kecakapan, dan tanggung jawab.14

Umar membagi aspek-aspek kinerja antara lain: mutu pekerjaan, kejujuran karyawan, inisiatif, kehadiran, sikap, kerjasama, keandalan, pengetahuan tentang pekerjaan, tanggung jawab, dan pemanfaatan waktu kerja. ${ }^{15}$ 


\section{Faktor-Faktor yang mempengaruhi Pencapaian Kinerja bagi tenaga kependidikan}

Secara umum, terdapat dua faktor yang mempengaruhi pencapaian kinerja, yaitu faktor kemampuan (ability) dan faktor motivasi (motivation). Hal ini sesuai dengan pendapat Keith Davis yang merumuskan bahwa:

$$
\begin{array}{ll}
\text { Human Performance } & =\text { Ability } \times \text { Motivation } \\
\text { Motivation } & =\text { Attitude } \times \text { Situation } \\
\text { Ability } & =\text { Knowledge } x \text { Skill16 }
\end{array}
$$

\section{Kemampuan (Ability)}

Secara psikologis, kemampuan (Ability) terdiri dari kemampuan potensi (IQ) dan kemampuan reality (knowledge + Skill). Artinya, pimpinan dan karyawan yang memiliki IQ di atas rata-rata (IQ 11 0-120) apalagi IQ superior, Very superior, gifted dan jenius dengan pendidikan yang memadai untuk jabatannya dan terampil dalam mengerjakan pekerjaan sehari-hari, maka akan lebih mudah mencapai kinerja maksimal.

\section{Pendidikan}

Pendidikan merupakan prinsip utama bagi kelangsungan hidup setiap bangsa karena pendidikan dapat dipandang sebagai suatu proses untuk membawa perubahan yang sesuai dengan tingkah laku yang diharapkan oleh seseorang atau masyarakat. Perubahan tingkah laku yang diharapkan dalam pendidikan menurut Purwanto adalah:

a. Perubahan tentang apa yang diketahui, yaitu pengetahuan.

b. Perubahan tentang apa yang dipikirkan, yaitu sikap.

c. Perubahan tentang apa yang dilakukan, yaitu keterampilan.

d. Perubahan tentang apa yang diinginkan, yaitu motivasi. ${ }^{17}$

Perubahan-perubahan yang terjadi terhadap pengetahuan, sikap, keterampilan, dan motivasi akan mempercepat ke arah kedewasaan dengan ciri-ciri menampakkan diri dengan bentuknya, beranggapan mempunyai ketepatan, merdeka, tetap stabil, kuat, membantu, tahu mengambil dan menentukan jalan, tidak tergantung orang lain. ${ }^{18}$

Nasution juga berpendapat bahwa pendidikan berkenaan dengan perkembangan dan perubahan kelakuan yang dididik. Pendidikan bertalian dengan transmisi pengetahuan, sikap, kepercayaan, keterampilan, dan aspek-aspek kelakuan lainnya kepada generasi muda. Pendidikan adalah proses mengajar dan belajar pola-pola kelakuan manusia menurut apa yang diharapkan oleh masyarakat. ${ }^{19}$

Kartono mengemukakan bahwa pendidikan merupakan rangkaian kegiatan yang intensional, bertujuan, disengaja, direncanakan, diorganisir secara sistematis, diawasi, dinilai serta, dinilai ulang untuk menghasilkan prototype manusia terdidik yang bermutu dan efisien. Semakin jelaslah bahwa pendidikan adalah suatu kegiatan yang terencana dengan persyaratan tertentu seperti dilakukan dengan sadar, bertujuan, terorganisir secara sistematis dan seterusnya serta dapat diukur hasilnya. ${ }^{20}$ 


\section{Keterampilan (Skill)}

Skill adalah kemampuan, kemahiran, atau keahlian yang dimiliki pegawai dalam melaksanakan tugas pekerjaan, sehingga outputnya memberikan hasil yang berkualitas. Strategi untuk meningkatkan skill adalah peningkatan pendidikan formal, pengadaan latihan, pengembangan wawasan perbaikan kompensasi, baik sistem penggajian, maupun pemberian kompensasi, fasilitas kendaraan, perumahan, pakaian kerja, sehingga mendorong peningkatan kinerja sumber daya manusia dengan indikatornya adalah produktivitas yang tinggi, inovatif, disiplin, tangguh, loyalitas, dan dedikasi serta profesional.

Peningkatan kinerja melalui pendidikan dan tujuan meningkatkan kemampuan teoretis, konseptual, terampil, beretos kerja, profesional, produktif dan bertanggung jawab serta memiliki moral yang baik. Sedangkan melalui kegiatan pelatihan bertujuan meningkatkan kemampuan dan penguasaan teknis, memperbaiki dan memperbaharui budaya kerja yang lebih baik, sehingga mengurangi biaya produksi akibat kesalahan dan kekeliruan dalam proses produksi dan dapat meningkatkan kualitas kerja.

Menurut Simamora pelatihan sumber daya manusia adalah serangkaian aktivitas yang dirancang untuk meningkatkan keahlian-keahlian, pengetahuan, pengalaman ataupun perubahan sikap individu dengan pelatihan dan pengembangan sumber daya manusia, maka organisasi dapat melakukan evaluasi sekaligus memiliki hasil kerja karyawan (kinerja) guna peningkatan produktivitas pegawai. ${ }^{21}$ Simamora mengemukakan bahwa pelatihan dapat dibagi atas dua bagian yaitu pelatihan ditempat kerja (on the job training) yang meliputi kegiatan magang, internship, instruksi pekerjaan dan rotasi yang kedua adalah pelatihan di luar tempat kerja (off the job training) mencakup kuliah dan pelatihan. ${ }^{22}$

\section{Pengalaman Kerja}

Pengalaman kerja yang dimaksud adalah pengalaman kerja pegawai pada instansi/organisasi dimana mereka bekerja. Hal ini sesuai dengan pendapat Andrew E Sikula yang menyatakan bahwa pengalaman kerja seorang pegawai akan memberikan keterampilan dan pemahaman yang baik atas pekerjaan dibandingkan dengan pegawai yang tidak memiliki pengalaman kerja.

Thoha berpendapat bahwa merupakan salah satu unsur dalam kematangan berkaitan dengan pengetahuan dan keterampilan yang didapat dari pendidikan, pelatihan dan pengalaman. Kesimpulan para ahli bahwa pegawai (PNS) sangat terkait dengan tingkat pendidikan dan pelatihan. ${ }^{23}$

\section{Motivasi Kerja}

Kebutuhan dan tujuan adalah konsep yang memberikan dasar untuk menyusun suatu pola terpadu. Kebanyakan pimpinan selalu mempertimbangkan bagaimana memotivasi karyawan baik secara kelompok maupun individu dengan cara beragam dan dalam banyak hal tidak dapat diramaikan. Dengan keragaman ini menyebabkan perbedaan pola perilaku yang dalam beberapa hal berhubungan dengan kebutuhan dan tujuan. 
Kebutuhan berhubungan dengan kekurangan yang dialami oleh seseorang pada waktu tertentu. Kekurangan ini mungkin bersifat fisiologis, yakni kebutuhan dasar seperti kebutuhan akan penghargaan diri (self esteem), atau kebutuhan sosiologis yakni kebutuhan akan interaksi sosial. Kebutuhan dianggap sebagai penyakit, penguat, atau penggerak perilaku. Artinya, apabila dalam diri manusia terdapat kekurangan kebutuhan, maka manusia tersebut lebih peka terhadap usaha memotivasi dari pada pimpinan. Peluang atau kesempatan kepada karyawan untuk promosi dalam suatu jenjang jabatan dan sebagainya.

\section{Teori Maslow}

Inti teori Maslow ialah bahwa kebutuhan manusia tersusun dalam suatu hirarki dari tingkat yang paling rendah yaitu kebutuhan fisiologis dan tingkat paling tinggi yaitu kebutuhan keutamaan. Menurut Maslow, orang mencoba memenuhi kebutuhan yang lebih mendasar sebelum berusaha memenuhi kebutuhan yang lebih tinggi, kebutuhan yang telah terpenuhi bukan merupakan faktor motivator. kebutuhan berprestasi (n Ach), kebutuhan berafiliasi (n Aft)dan kebutuhan berkuasa (n Pow). ${ }^{24}$

Menurut Mc Clelland bahwa orang-orang yang mempunyai motivasi tinggi ditandai oleh (1) memilih untuk menghindari tujuan prestasi yang mudah dan sulit, (2) memilih umpan balik langsung dan dapat diandalkan mengenai bagaimana mereka berprestasi, dan (3) menyukai tanggung jawab pemecahan masalah. ${ }^{25}$

\section{Kedisiplinan}

Nitisemito mengartikan kedisiplinan sebagai suatu sikap, tingkah laku dan perbuatan yang sesuai dengan peraturan organisasi baik yang tertulis maupun tidak. ${ }^{26}$ Sedangan Hasibuan menjelaskan bahwa kedisiplinan sebagai kesadaran dan kesedian seseorang mentaati semua peraturan perusahaan dan norma-norma sosial yang berlaku. Kesadaran adalah sikap seseorang yang secara sukarela mentaati semua peraturan dan sadar akan tugas dan tanggung jawab, sedangkan kesedian adalah suatu sikap, tingkah laku dan perbuatan seseorang yang sesuai peraturan organisasi, baik yang tertulis maupun yang tidak tertulis. ${ }^{27}$

Menegakkan kedisiplinan penting bagi suatu organisasi, sebab dengan adanya kedisiplinan dapat diharapkan pekerjaan akan dilakukan seefektif dan seefisien mungkin. Dengan demikian, bilan kedisiplinan tidak dapat ditegakkan, kemungkinan tujuan yang telah ditetapkan tidak dapat efektif dan kurang efisien.

\section{Sarana dan Prasarana}

Faktor sarana ini juga tergolong penting dalam pelaksanaan dan penyelenggaraan aktivitas pegawai administrasi pada Fakultas Tarbiyah dan Keguruan UIN Alauddin Makassar. Dalam pengertian ini, peralatan adalah setiap benda atau alat yang digunakan untuk memperlancar atau mempermudah pekerjaan atau gerak aktivitas pemerintah daerah.

Dari pengertian di atas jelaslah bahwa alat pertama-tama merupakan sarana perantara yang dipergunakan oleh manusia dalam melakukan aktivitasnya guna men- 
capai tujuan yang dikehendaki. Dalam hubungannya dengan pengertian di atas peralatan yang dimaksud di sini termasuk manusia, karena manusia menurut hemat penulis merupakan komponen tersendiri yang menduduki posisi sentral dan penyelenggaraan organisasi. Peralatan yang dimaksudkan hanya menyangkut perangkat keras (hardware), misalnya gedung ruang; peralatan dan perkantoran (mesin, tik, kertas, meja, kursi, lemari, dan sebagainya).

Dalam penelitian ini ditemukan bahwa kinerja pegawai pada Fak. Tarbiyah dan Keguruan UIN Alauddin Makassar dalam kategori tinggi, ini menunjukkan bahwa pegawai telah mampu menunjukkan profesionalismenya dalam melaksanakan pekerjaan yang dibebankan oleh atasan atau pimpinan mereka.

Kinerja tenaga kependidikan ini dapat dilihat dari keleluasaan individu dalam penyelesaian pekerjaan, situasi kerja yang cukup kondusif, kecakapan dan kemampuan tenaga kependidikan dalam menghadapi kondisi kerja yang semakain menantang, kreativitas memperbaharui metode kerja, keakuratan pelaksanaan hasil pekerjaan dan kesempatan masyarakat memberikan kritikan.

\section{Pengaruh Kemampuan terhadap Kinerja Tenaga Kependidikan}

Hasil analisis pengaruh kemampuan pegawai terhadap kinerja pegawai terhadap kinerja pegawai menunjukkan bahwa kemampuan pegawai berpengaruh dominan terhadap kinerja pegawai. Hal ini dapat dilihat dari kontribusi variabel kemampuan adalah $24,8 \%$ terhadap kinerja pegawai. Hasil ini sejalan dengan hasil penelitian yang dilakukan oleh Muh. Nur yang menemukan bahwa kemampuan berpengaruh dominan terhadap kinerja pegawai. Kemampuan pegawai adalah merupakan salah satu faktor yang menentukan bagi keberhasilan pelaksanaan tugas yang dibebankan kepadanya. Dengan adanya kemampuan yang dimiliki sesuai dengan persyaratan analisa jabatan diharapkan pegawai yang bersangkutan dapat melaksanakan tugastugasnya secara efektif dan efisien. Sehingga kinerja pegawai yang bersangkutan dengan sendirinya akan meningkat. ${ }^{28}$

Berdasarkan uraian di atas, maka jelas bahwa pelaksanaan tugas sesuai dengan yang diharapkan baik dilihat dari segi kuantitas maupun kualitas, akan dapat apabila para pegawai yang bersangkutan mempunyai kemampuan yang dipersyaratkan. Kemampuan pegawai dapat diperoleh melalui pendidikan, pelatihan dan pengalaman. Pendidikan pegawai pada Fakultas Tarbiyah dan Keguruan UIN Alauddin Makassar rata-rata Sarjana (S1) yang menunjukkan bahwa kemampuan dari segi ilmu pengetahuan tergolong tinggi.

Sedangkan keterampilan pegawai juga termasuk dalam kategori tinggi, hal ini disebabkan seringnya pegawai diikutkan dalam pelatihan-pelatihan baik secara lokal maupun di tingkat nasional. Kebijakan pimpinan untuk memberikan/mendorong pegawainya untuk mengikuti pelatihan merupakan langkah yang sangat tepat untuk meningkatkan efektivitas kerja pegawai. Sedangkan pengalaman pegawai pada umumnya cukup berpengalaman dalam bidang tugasnya sehingga mereka sudah paham betul mengenai pekerjaan yang diberikan oleh pimpinan. 
Menurut Siagian, bahwa terdapat manfaat dari penyelenggaraan program pelatihan, yaitu peningkatan produktivitas kerja organisasi secara keseluruhan, terwujudnya hubungan yang serasi antara atasan dan bawahan dan terjadinya proses pengambilan keputusan yang lebih cepat dan tepat. Dalam pelatihan tercakup di dalamnya kesempatan belajar, tidak terbatas pada upaya perbaikan performance pekerja pada pekerjaan sekarang saja, tetapi juga mempunyai jangkauan yang lebih luas. ${ }^{29}$

\section{Pengaruh Motivasi Terhadap Produktivitas Pegawai}

Motivasi merupakan energi dalam diri seseorang yang ditandai oleh "feeling" dan didahului oleh tanggapan terhadap tujuan. Selanjutnya dikemukakan bahwa motivasi mengandung tiga elemen penting yaitu (a) motivasi mengawali perubahan energi pada diri setiap individu, karena menyangkut perubahan energi manusia, penampakan akan menyangkut kegiatan fisik; (b) motivasi ditandai oleh adanya rasa atau feeling, atau afeksi seseorang. Dalam hal ini motivasi ada hubungannya dengan kejiwaan, afeksi, dan emosi yang dapat menentukan tingkah laku manusia; (c) motivasi akan terangsang karena adanya tujuan. Motivasi merupakan respon dari tujuan, tujuan ini menyangkut kebutuhan. ${ }^{30}$

Hasil analisis menunjukkan bahwa rata-rata motivasi pegawai berada dalam kategori sedang. Hal ini terlihat dari 10 item pertanyaan yang diajukan kepada responden yakni pemberian penghargaan berupa pujian berategori cukup sering, penghargaan diberikan secara rutin berkategori cukup sering, keseringan mendapat promosi jabatan berkategori, promosi jabatan didasarkan prestasi kerja berkategori tidak pernah, promosi jabatan dinilai secara objektif berkategori jarang, ketersedian dana dalam pelaksanaan tugas berkategori cukup sering, pengalokasian dana tambahan untuk kesejahteran pegawai berkategori sering, perlibatan secara bergilir pegawai dalam suat kegiatan berkategori cukup sering, honor dalam setiap pelaksanaan tugas berkategori cukup sering dan selain honor kegiatan, mendapat honor lain dari instansi berkategori cukup sering.

Penulis berpendapat bahwa sumber daya manusia adalah (tenaga kerja) yang akan bergerak untuk bekerja jika terpenuhi kebutuhan-kebutuhannya. Dengan terpenuhi kebutuhan seperti yang diharapkan akan membentuk sikap mental yang mendorong untuk selalu berprestasi dan jika lingkungan kerja mendukung maka pencapaian kinerja akan lebih baik dan mudah untuk mencapai tujuan organisasi atau perusahaan.

\section{Pengaruh Kedisiplinan Terhadap Kinerja Tenaga Kependidikan}

Masalah disiplin pegawai negeri sipil (PNS) pada dasarnya telah diatur dalam peraturan pemerintah (PP) No. 30 Tahun 1980 Tentang disiplin PNS, GBHN/Tap MPR No. XXII Tahun 2002, termasuk peraturan perundang-undangan lainnya. Peraturan perundang-undangan pada dasarnya menjadi acuan pada setiap instansi pemerintah untuk mendisiplinkan para pegawainya sesuai dengan mekanisme yang 
telah ditetapkan.

Disiplin kerja mencakup tingkat kepatuhan atau ketaatan pegawai dalam mengikuti seluruh tata tertib kerja organisasi yang berlaku pada Fakultas Tarbiyah dan Keguruan UIN Makassar disiplin kerja relatif berpengaruh terhadap kinerja pegawai dan organisasi. Apa dan bagaimana disiplin kerja pegawai tersebut, dilihat dari beberapa indikator yang diteliti: (a) ketaatan terhadap peraturan, (b) ketepatan penggunaan waktu, (c) ketepatan dalam pelaksanaan tugas, dan (d) kepatuhan pada pimpinan. ${ }^{31}$

Analisis terhadap disiplin kerja tenaga kependidikan pada Fakultas Tarbiyah dan Keguruan UIN Alauddin Makassar dalam pelaksanaan tugasnya menunjukkan bahwa tingkat kedisiplin pegawai berada dalam kategori sedang. Olehnya itu masih perlu peningkatan kedisiplinan terhadap tenaga kependidikan. Peningkatan kedisiplinan pegawai dapat ditempuh dengan pembelakuan aturan yang ketat oleh pimpinan terhadap semua tenaga kependidikan yang ada di Fakultas Tarbiyah dan Keguruan UIN Alauddin Makassar. Pegawai yang melanggar harus diberikan sanksi (punishment) dan rajin diberikan penghargaan (reward) sesuai dengan peraturan yang berlaku.

\section{Pengaruh Sarana dan Prasarana Terhadap Kinerja Pegawai}

Hasil analisis deskriptif menunjukkan bahwa sarana pada Fakultas Tarbiyah dan Keguruan UIN Alauddin Makassar termasuk dalam kategori sudah meningkat karena dalam pelayanan adminstrasi akademik melalui online. Ini menunjukan sarana pendukung pelaksanan tugas tenaga kependidikan sudah tersedia dalam jumlah yang cukup memadai. Sarana dan prasarana yaitu ketersediaan sarana komputer, sarana komunikasi dan ruangan yang memenuhi kriteria ruang perkantoran yang baik.

Muh. Nur mengemukakan bahwa sarana dan prasarana berpengaruh terhadap kinerja tenaga kependidikan. Sedangkan hasil analisis secara parsial menunjukkan bahwa sarana berpengaruh terhadap kinerja pegawai pada Fakultas Tarbiyah dan Keguruan UIN Alauddin Makassar. Ini berarti perlunya peningkatan kualitas dan kuantitas sarana untuk menunjang lancarnya kegiatan pegawai. Yang terpenting adalah adanya kesejahteraan bagi tenaga kependidikan yang diberikan oleh pimpinan fakultas berupa insentif setiap bulan dan honor tambahan apabila ada tugas-tugas tambahan yang diberikan oleh pimpinan Fakultas Tarbiyah dan Keguruan.

\section{SIMPULAN}

Berdasarkan hasil penelitian dan pembahasan yang telah dikemukakan di atas dapat ditarik beberapa kesimpulan sebagai berikut:

1. Hasil analisis secara simultan menunjukkan bahwa terdapat pengaruh yang signifikan antara kemampuan pegawai, motivasi, kedisiplinan serta sarana dan prasarana terhadap kinerja tenaga kependidikan pada Fak. Tarbiyah dan Keguruan UIN Alauddin Makassar.

2. Hasil analisis secara parsial menunjukkan bahwa variabel kemampuan pegawai 
berpengaruh dominan dan signifikan terhadap kinerja pegawai Fak. Tarbiyah dan Keguruan UIN Alauddin Makassar. Ini berarti bahwa peningkatan kemampuan pegawai berupa peningkatan jenjang pendidikan, mengikuti pelatihan akan mampu meningkatkan kemampuan bekerja pegawai yang berpengaruh pada peningkatan kinerja bagi tenaga kependidikan.

3. Secara parsial menunjukkan bahwa variabel motivasi berpengaruh terhadap kinerja tenaga kependidikan pada Fakultas Tarbiyah dan Keguruan UIN Alauddin Makassar. Ini berarti bahwa peningkatan motivasi pegawai akan mampu meningkatkan dorongan dan gairah kerja pegawai yang berdampak pada peningkatan kinerja bagi tenaga kependidikan.

\section{CATATAN AKHIR:}

1. Veithzal Rivai, Manajemen Sumber Daya Manusia, Edisi II, Murai Kencana: Jakarta, 2003, h. 81.

2. Nitisemito, Manajemen Personalia, (terjemahan), Ghalia Indonesia: Jakarta. 1996, h. 11.

3. Henri Simamora, Manajemen Sumber Daya Manusia, Yokjakarta, 2001, h. 20.

4. Veithzal Rivai, op.cit., h. 8.

5. Ibid., h. 3 .

6. Mangkunegara, Evaluasi Kinerja SDM, PT. Refika Aditama: Bandung, 2005, h. 67.

7. Ibid, h. 67.

8. Ibid, h. 76.

9. Ibid, h. 69 .

10. Ibid, h. 69.

11. Ibid, h. 72 .

12. Ibid, h. 74 .

13. Ibid, h. 81 .

14. Ibid, h. 81.

15. Ibid, h. 81.

16. Ibid, h. 67.

17. Ngalim Purwanto, Psikologi Pendidikan, Bursa IKIP: Jakarta, h. 17.

18. S. Nasution, Sosiologi Pendidikan, Bumi Aksara: Jakarta, 1996, h. 10.

19. Ibid, h. 10.

20. Kartini Kartono, Pengantar Umum Mendidik Teoritis, Mandar Maju: Bandung, 1992, h. 24.

21. Henri Simamora, op. cit., h. 349.

22. Ibid, h. 153

23. Miftah Thoha, Perilaku Organisasi, RajaGrafindo Persada: Jakarta, h. 54.

24. A. Maslow, Motivasi dan Kepribadian, Teori Motivasi dengan Ancang Hirarki Kebutuhan Manusia, Terjemahan, PT. Pustaka Barman Presindo: Jakarta, 1994.

25. Sondang P. Siagian, Teori Motivasi dan Aplikasinya, Rineke Cipta: Jakarta, h. 238.

26. Nitizemito, op. cit., h. 118.

27. Malayu SP. Hasibuan, Manajemen Sumber Daya Manusia, PT. Aksara: Jakarta, 2000, h. 190.

28. Ibid.,

29. Sondang P. Siagian, h.238.

30. Ibid., 
31. PP No. 30. th 1980. Disiplin pegawai Negeri Sipil, GBHN, Tap MPR, No. xxii. Th 2002, Peraturan Perundang- Undangan.

\section{DAFTAR PUSTAKA:}

Derssiler, Garry, Manajemen Sumber daya Manusia, Terjemahan oleh Benyamin Molan, Jilid II, PT Dadi Kayana: Jakarta, 1984.

Hall, H., "Indonesia's Industrial Trasmormasion", part 1 \& 2, Bulletin Of Indonesia Economic Studies, Vol. 26, No. 2\& 3, 1974.

Hasibuan, Malayu SP., Manajemen Sumber Daya Manusia, PT. Aksara: Jakarta, 2000.

Hasna, Wahyuni S., Srategi Peningkatan Kinerja Pegawai dan Fakto-Faktor Yang mempengaruhinya pada badan pengawasan Daerah Propensi Sulawesi Selatan. Tesis PPS UMI Makassar, 2005

Jayakusuma, Prestasi dalam Dunia Kerja, PT. Gramedia Pustaka Utama: Jakarta, 1999.

Kartono, Kartini, Pengantar Umum Mendidik Teoritis, Mandar Maju: Bandung, 1992.

Lubis, S .B., dan Husaini, Teori Organisasi: Suatu Pendekatan Makro, Pusat Antar Universitas Ilmu-Ilmu Sosial, Universitas Indonesia: Jakarta, 1987.

Malik, Teori Motivator-Higine dan Pola Motivasi Kerja Indonesia, Bussines News, 1996.

Mangkunegara, Evaluasi Kinerja SDM, PT. Refika Aditama: Bandung, 2005.

Mangkunegara, Evaluasi Kinerja SDM, PT. Refika Aditama: Bandung, 2005.

Maslow, A., Motivasi dan Kepribadian, Teori Motivasi dengan Ancang Hirarki Kebutuhan Manusia, Terjemahan, PT. Pustaka Barman Presindo. Jakarta, 1984.

Nasution, S., Sosiologi Pendidikan, Bumi Aksara: Jakarta, 1996.

Nitisemito, Manajemen Personalia, (terjemahan), Ghalia Indonesia: Jakarta. 1996.

PP No. 30. th 1980. Disiplin pegawai Negeri Sipil, GBHN, Tap MPR, No. xxii. Th 2002, Peraturan Perundang- Undangan.

Purwanto, Ngalim, Psikologi Pendidikan, Bursa IKIP: Jakarta.

Rivai, Veithzal, 2003. Manajemen Sumber Daya Manusia, Edisi II, Murni Kencana: Jakarta, 2003.

Siagian, Sondang P., Teori Motivasi dan Aplikasinya, Rineke Cipta: Jakarta, 1995.

Simamora, Henri, Manajemen Sumber Daya Manusia, Yokjakarta, 2001.

Thoha, Miftah, Perilaku Organisasi, RajaGrafinda Persada: Jakarta, 1994. 